\title{
PRZESZKODY MAŁŻEŃSKIE W KODEKSIE RODZINNYM I OPIEKUŃCZYM1ㅗำ
}

Treść: Uwagi wprowadzające. - 1. Przeszkody w ogólności (katalog, ratio legis). - 2. Poszczególne przeszkody małżeńskie. - Uwagi końcowe.

\section{Uwagi wprowadzające}

Problematyka stanowiąca przedmiot referatu obejmuje szereg szczegółowych i złożonych zagadnień prawnych. Z kolei ramy czasowe, jak również forma przedłożenia, nie pozwalają na omówienie ich w tym samym stopniu szczegółowości. Z konieczności zatem niektóre zagadnienia zostaną omówione szerzej, jak np. przeszkoda ubezwłasnowolnienia całkowitego oraz przeszkoda choroby psychicznej albo niedorozwoju umysłowego, inne natomiast - np. przeszkoda pokrewieństwa i powinowactwa - jedynie zasygnalizowane.

${ }^{1}$ Artykuł jest rozszerzoną wersją referatu wygłoszonego na konferencji dotyczącej przeszkód małżeńskich, zorganizowanej przez Wydział Prawa Kanonicznego UKSW w Warszawie, w dniu 25 kwietnia 2012 r. Zaproponowany przez organizatorów konferencji tytuł referatu brzmiał: „Pozostałe przeszkody do zawarcia małżeństwa w polskim prawie rodzinnym”. Termin ,pozostałe” odnosił się do wcześniejszego referatu wygłoszonego na tej konferencji przez prof. W. Stojanowską, dotyczącego wieku jako przeszkody do zawarcia małżeństwa. Oba referaty z woli organizatorów stanowić miały pewną całość. Przedmiotem referatu były zatem inne - poza wiekiem - przeszkody do zawarcia małżeństwa przewidziane w KRO. Zasadnicza treść referatu została zachowana, zmianie uległ jego tytuł. 
W tytule referatu użyty został termin „przeszkody małżeńskie”. Warto w tym kontekście przypomnieć, że nie jest to termin ustawowy. Ustawodawca prawno-rodzinny w odniesieniu do przedmiotu rozważań posługuje się zazwyczaj formułą opisową: „nie może zawrzeć małżeństwa" (art. 10, 11, 12, 13 KRO) lub „nie mogą zawrzeć małżeństwa” (art. 14 i 15 KRO). Stosuje również inne terminy, np. „okoliczności wyłączające zawarcie małżeństwa” (art. 5 i 9 KRO), „okoliczności stanowiące podstawę unieważnienia” (art. 20 § 2 KRO), czy też „powód unieważnienia" (np. art. 18 KRO)2 ${ }^{2}$. Doktryna posługiwała się często pojęciem „zakaz zawarcia małżeństwa”, a nawet „małżeństwo zakazane”3. W nowszych publikacjach z zakresu prawa rodzinnego powraca się do terminu ,przeszkody małżeńskie"4.

\section{Przeszkody w ogólności (katalog, ratio legis)}

Zgodnie z art. 17 Kodeksu rodzinnego i opiekuńczego małżeństwo może zostać unieważnione tylko z przyczyn przewidzianych w Kodeksie. Przepis ten wprowadza zasadę numerus clausus przeszkód do zawarcia małżeństwa. Małżeństwo może zostać unieważnione wyłącznie na podstawie przyczyn (powodów) określonych w ustawie. Są nimi:

- nieosiągnięcie wymaganego wieku,

- ubezwłasnowolnienie całkowite.

- choroba psychiczna albo niedorozwój umysłowy,

- bigamia,

- pokrewieństwo i powinowactwo,

- stosunek przysposobienia 5 .

${ }^{2}$ Szczegółowiej na ten temat por. J. WinIARZ, w: System prawa rodzinnego i opiekuńczego, pod red. J. St. Piątowskiego, Warszawa 1985, s. 162 i n.

3 Por. np. J. GóRecki, Unieważnienie malżeństwa, Kraków 1958, s. 6.

${ }^{4}$ Por. np. T. Smyczyński, Prawo rodzinne i opiekuńcze. Analiza i wykładnia, Warszawa 2001, s. 64 i n.; J. Ignatowicz, M. NazAr, Prawo rodzinne, Warszawa 2005, s. $95 \mathrm{i} \mathrm{n}$.

5 Do wymienionego w treści katalogu przeszkód małżeńskich doktryna zalicza również wadliwe pełnomocnictwo (art. $16 \mathrm{KRO}$ ). W odróżnieniu do pozostałych przeszkód przepis art. $16 \mathrm{KRO}$ nie dotyczy bezpośrednio nupturientów, ich „zdatności” do zawarcia małżeństwa, ale pewnego „narzędzia prawnego”, umożliwiającego w pewnych przypadkach zawarcie małżeństwa oraz jego unieważnienie. Zagadnienie to nie jest 
Wymieniony powyżej katalog przeszkód do zawarcia małżeństwa jest wynikiem ewolucji, jaka dokonała się w polskim prawie rodzinnym w tym zakresie. Warto w tym miejscu poświęcić kilka słów aspektowi historycznemu omawianego zagadnienia. Kodeks rodzinny z 1950 roku przewidywał węższy katalog przeszkód niż ustawa obecnie obowiązująca (bigamię, pokrewieństwo, powinowactwo, przysposobienie, chorobę psychiczną oraz brak wymaganego wieku). Dekret Prawo małżeńskie z 25 września 1945 roku - poza przeszkodami takimi jak: wiek, pokrewieństwo, powinowactwo, przysposobienie, choroba psychiczna - do katalogu przeszkód małżeńskich zaliczał także małżonkobójstwo. W art. 7 pkt 5 ustawodawca stanowił: „nie mogą zawrzeć małżeństwa ze sobą osoby, z których chociażby jedna, celem umożliwienia małżeństwa, nastawała na życie małżonka swego lub małżonka drugiej

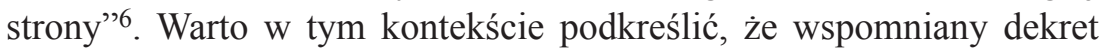
$\mathrm{w}$ art. 5 stanowił nadto, że związek małżeński jest ważnie zawarty, jeżeli małżonkowie mają prawną zdolność do zawarcia małżeństwa, tzn. ukończyli 18 rok życia. W trakcie prac nad Kodeksem rodzinnym ustawodawca zrezygnował z kategorii zdolności do zawarcia małżeństwa, ograniczając się do unormowania przeszkód do zawarcia małżeństwa. Podobne rozwiązanie przyjął ustawodawca w trakcie prac nad KRO. Wypada jednak wspomnieć, że w ramach prac kodyfikacyjnych nad nowym Kodeksem (KRO) toczyła się dyskusja nad pojęciem zdolności do zawarcia małżeństwa i zasadnością jej kodeksowego ujęcia. W doktrynie reprezentowano różne stanowiska, także co do charakteru prawnego owej zdolności. Postrzegano ją jako swoisty ,wycinek” zdolności prawnej i zarazem zdolności do czynności prawnych ${ }^{7}$. Reprezentowany był również pogląd, zgodnie z którym zdolność do zawarcia małżeństwa jest zdolnością szczególną i nie mieści się w zdolności prawnej

przedmiotem niniejszych rozważań. Warto wspomnieć, że artykuł $15^{1} \mathrm{KRO}$ przewiduje również możliwość unieważnienia małżeństwa z powodu stanu wyłączającego świadome wyrażenie woli, błędu co do tożsamości drugiej strony oraz bezprawnej groźby. Przyczyny te stanowią odrębną od przeszkód kategorię prawną - wad oświadczenia woli - dlatego również nie będą one przedmiotem zainteresowania w niniejszym referacie.

${ }^{6}$ Por. Prawo familijne wraz z przepisami ogólnymi prawa cywilnego, Poznań 1947.

7 Por. J. GóreCKI, op. cit., s. 43 i n. 
regulowanej w KC. Ostatecznie przeważył pogląd, że wprowadzenie do przepisów KRO pojęcia zdolności do zawarcia małżeństwa jest zbędne oraz że kategoria ta jest na gruncie obowiązujących przepisów KRO bezprzedmiotowa. Ustawodawcy chodzi bowiem nie o zdolność do zawarcia małżeństwa, lecz wyłącznie o ewentualne podstawy unieważnienia małżeństwa zawartego, a więc ważnego ${ }^{8}$.

Obowiązujący w KRO katalog przeszkód do zawarcia małżeństwa można klasyfikować za pomocą różnych kryteriów. Zwykle wspomniane przeszkody dzieli się na bezwzględne (w odniesieniu do których nie ma możliwości uzyskania zezwolenia sądu na zawarcie małżeństwa, np. przeszkoda pokrewieństwa, bigamii) i względne - możliwe do „uchylenie" w poszczególnym przypadku decyzją sądu (np. przeszkoda wieku, choroby psychicznej albo niedorozwoju umysłowego). Inna klasyfikacja dokonywana jest za pomocą kryterium podmiotów uprawnionych do żądania unieważnienia małżeństwa w przypadku zaistnienia określonej przeszkody. Przyjmując to kryterium, wyróżnia się przeszkody, w przypadku których unieważnienia małżeństwa mogą żądać tylko małżonkowie (przeszkoda wieku, ubezwłasnowolnienia, choroby psychicznej), oraz przeszkody, w odniesieniu do których unieważnienia małżeństwa może żądać każdy, kto ma w tym interes prawny (np. przeszkoda pokrewieństwa, bigamii). ${ }^{9}$

Omawiając instytucję przeszkód do zawarcia małżeństwa, nie sposób pominąc kwestię ratio legis tej instytucji. Zwykle jako uzasadnienie wprowadzonych przez ustawodawcę ograniczeń w zawieraniu małżeństw przywołuje się w literaturze względy natury obyczajowej, moralnej i eugenicznej. Wskazuje się również na społeczne funkcje małżeństwa i związane z nimi cele. J. Górecki w swej monografii Unieważnienie małżeństwa wskazuje na dwa zasadnicze cele małżeństwa: osiągnięcie pełni rozwoju i szczęścia oraz zrodzenie i wychowanie zdrowego potomstwa. Realizacja tych celów służy nie tylko małżonkom, ale

8 Por. J. Winiarz, w: System prawa rodzinnego i opiekuńczego, op. cit., s. 170.

9 Wyjątek stanowi w tej klasyfikacji przeszkoda wadliwego pełnomocnictwa, w przypadku której unieważnienia małżeństwa może żądać jedynie mocodawca (udzielający pełnomocnictwa). 
całemu społeczeństwu. Dlatego, zdaniem Góreckiego: ,zawarte w ustawie zakazy powinny wykluczać zawieranie małżeństw, co do których istnieje daleko idące prawdopodobieństwo, że nie będą związkami dobrze funkcjonującymi i trwałymi (...)"10. Autor wskazuje tym samym na społeczne funkcje omawianej instytucji przeszkód małżeńskich.

\section{Poszczególne przeszkody małżeńskie}

W art. 11 Kodeksu rodzinnego i opiekuńczego ustawodawca stwierdza: „nie może zawrzeć małżeństwa osoba ubezwłasnowolniona całkowicie”. Ze sformułowania tego jednoznacznie wynika, że przeszkodą objęta jest jedna postać ubezwłasnowolnienia - ubezwłasnowolnienie całkowite. Jest ono orzekane przez sąd, gdy - zgodnie z art. 13 Kodeksu cywilnego osoba, która ukończyła lat 13, z przyczyn wskazanych przez ustawodawcę, ,nie jest w stanie kierować swym postępowaniem.” Cytowany przepis art. $13 \mathrm{KC}$, jako przyczyny niemożności kierowania przez osobę swym postępowaniem, stanowiącej przesłankę ubezwłasnowolnienia całkowitego, wymienia chorobę psychiczną, niedorozwój umysłowy oraz innego rodzaju zaburzenia psychiczne (w szczególności pijaństwo i narkomanię). Nie ulega wątpliwości, że wymienione przyczyny nie są same w sobie przeszkodą do zawarcia małżeństwa na podstawie omawianego art. 11 KRO Przepis ten nie dotyczy bowiem sytuacji faktycznej osób chcących zawrzeć małżeństwo - jak ma to miejsce w przypadku art. $12 \mathrm{KRO}^{11}$-ale ich sytuacji prawnej - tzn. istnienia lub nieistnienia ubezwłasnowolnienia całkowitego. Zakaz zawarcia małżeństwa sformułowany w art. 11 KRO pojawia się jako skutek ubezwłasnowolnienia jako takiego.

W doktrynie i judykaturze utrwalił się pogląd, zgodnie z którym do orzeczenia ubezwłasnowolnienia całkowitego nie wystarczy pozytywna weryfikacja w każdym poszczególnym przypadku ustawowych jego przesłanek. Konieczne jest również istnienie celu ubezwłasnowolnienia, jakim jest pomoc osobie (w zakresie jej spraw osobistych i majątkowych.), w stosunku do której ma zostać orzeczone ubezwłasnowol-

10 J. GÓRECKI, Unieważnienie małżeństwa, op. cit., s. 5.

11 Por. A. Zielonacki, w: Kodeks rodzinny i opiekuńczy. Komentarz, pod red. H. DoLECKIEGO I T. SoKoŁowskiego, Warszawa 2010, s. 55. 
nienie $^{12}$. Celem tym, jak wskazuje Sąd Najwyższy, nie może być np. ochrona osoby, której dobra mogą zostać zagrożone w wyniku zachowań osoby chorej (orz. z 15 maja 1969 r. I CR 132/68)13.

Wymienione $\mathrm{w}$ przepisie art. 13 Kodeksu cywilnego przyczyny ubezwłasnowolnienia całkowitego - choroba psychiczna i niedorozwój umysłowy - tworzą samoistną przeszkodę małżeńską. Zgodnie bowiem $\mathrm{z}$ art. $12 \mathrm{KRO}$ nie może zawrzeć małżeństwa „osoba dotknięta chorobą psychiczną albo niedorozwojem umysłowym”. Przeszkoda ta nie ma charakteru bezwzględnego. Ustawodawca stwarza możliwość zawarcia małżeństwa osobom, których omawiana przeszkoda dotyczy, o ile stan zdrowia lub umysłu takiej osoby nie zagraża małżeństwu ani zdrowiu przyszłego potomstwa oraz jeżeli osoba ta nie została ubezwłasnowolniona całkowicie. Stosownego zezwolenia na zawarcie małżeństwa w opisanym wyżej przypadku udziela sąd opiekuńczy w trybie postępowania nieprocesowego. Warto podkreślić, że sąd, rozpatrując wniosek strony, jest zobowiązany zgodnie z art. $561 \S 3$ KPC zasięgnąć opinii biegłego lekarza, w miarę możliwości psychiatry.

Wykładnia językowa omawianego przepisu art. 12 § $1 \mathrm{KRO}$ w zakresie ustawowych przesłanek wymaganych do udzielenia zezwolenia na zawarcie małżeństwa przez osobę dotkniętą chorobą psychiczną albo niedorozwojem umysłowym prowadzi do wniosku, że przedmiotowe zezwolenie nie powinno zostać udzielone, jeżeli stan zdrowia takiej osoby zagraża samemu małżeństwu lub zdrowiu przyszłego potomstwa. $\mathrm{Z}$ brzmienia przepisu wynika, że są to przesłanki rozłączne.

W doktrynie dominuje pogląd, zgodnie z którym choroba psychiczna (lub niedorozwój umysłowy) zagraża małżeństwu, jeżeli wyłącza spełnianie przez małżonków ról i funkcji charakteryzujących ,,przeciętne społecznie małżeństwo" ${ }^{14}$, w wyniku np. niemożności powstania trwa-

12 Szczegółowiej na ten temat por. M. Pazdan, w: Kodeks cywilny. Tom 1, Komentarz do art. 1-449, pod red. K. Pietrzykowskiego, wyd. 4, C.H.Beck, Warszawa 2005, s. $88 \mathrm{i} \mathrm{n.}$

13 Tamże, s. 88.

14 Por. K. Piasecki, w: Kodeks rodzinny i opiekuńczy. Komentarz, pod red. K. Piaseckiego, wyd. 4, Warszawa 2000, s. 90. 
łych więzi (duchowej, fizycznej i gospodarczej). W odniesieniu do drugiej z wymienionych przesłanek dominuje pogląd, zgodnie z którym użyte przez ustawodawcę określenie „zdrowie potomstwa” należy interpretować $\mathrm{w}$ sensie szerszym, niż wynikałoby to $\mathrm{z}$ jego literalnego brzmienia. Celem ustawodawcy w tym przypadku jest nie tylko ochrona dziecka przed ewentualną możliwością przekazania mu choroby psychicznej (zdrowie fizyczne i psychiczne), ale również w sytuacji, w której choroba psychiczna rodzica mogłaby znacząco wpływać na właściwy proces wychowawczy, powodując jego wypaczenie (orz. SN z 29 grudnia 1978 r. $)^{15}$. Część autorów, mimo akceptacji co do zasady opisanego wyżej stanowiska SN, wskazuje jednak na nieprecyzyjność ustawodawcy w zakresie redakcji omawianej przesłanki, która może prowadzić do różnych jego interpretacji ${ }^{16}$.

Przeszkoda choroby psychicznej albo niedorozwoju umysłowego budziła i budzi liczne kontrowersje. W doktrynie podnosi się między innymi, że brak obowiązkowych przedślubnych badań lekarskich powoduje trudność w ocenie, czy określony stan faktyczny wypełnia przesłanki objęte dyspozycją normy art. $12 \mathrm{KRO}$. Ma to znaczenie tym większe, że w praktyce ocenę w tym zakresie formułuje kierownik USC, który merytoryczne nie jest przygotowany do stwierdzenia istnienia omawianej przeszkody w określonym stanie faktycznym - zakwalifikowania określonych zachowań jako przejawu choroby psychicznej. Problemu tego - zdaniem wspomnianych autorów - nie rozwiązuje w pełni możliwość zwrócenia się przez kierownika USC do sądu o rozstrzygnięcie, czy w danym przypadku małżeństwo może zostać zawarte (art. 5 ustawy Prawo o aktach stanu cywilnego). Powyższe uwagi skłaniają tych autorów do formułowania pod adresem ustawodawcy postulatu uchylenia przepisu art. $12 \mathrm{KRO}$ i wprowadzenia obowiązku badań przedślubnych ${ }^{17}$. Rezygnacja z zakazu objętego przepisem art. $12 \mathrm{KRO}$ - zdaniem wspomnianych autorów - nie osłabia ochrony małżeństwa. Funkcje zakazu wynikającego z art. $12 \mathrm{KRO}$,przejęłyby przepisy o zakazie zawierania

\footnotetext{
15 II CR 475/78, OSPiKA 1980, nr 7-8, poz. 14.

16 Por. J. Winiarz, Prawo rodzinne, s. 63; por. także A. Zielonacki, op. cit., s. 56.

17 A. Zielonacki, op. cit., s. 61.
} 
małżeństwa przez osoby ubezwłasnowolnione całkowicie oraz przepisy o wadach oświadczenia woli przy zawieraniu małżeństwa"18.

Wspomniana instytucja lekarskich badań przedślubnych nie jest obca polskiemu prawa rodzinnemu. Wprowadzał ją np. art. 10 pkt 3 dekretu Prawo małżeńskie z 1945 roku. Dyskusje na ten temat toczyły się również w trakcie prac nad uchwaleniem Kodeksu rodzinnego i opiekuńczego oraz przy okazji dziesiątej rocznicy jego uchwalenia ${ }^{19}$. W doktrynie od dawna zgłaszano propozycje rozwiązań prawnych, umożliwiających wprowadzenie do polskiego prawa rodzinnego omawianej instytucji. Szczególnie interesująca wydaje się propozycja M. Safjana. Wymienia on cztery możliwe sposoby podejścia ustawodawcy do omawianego problemu:

1. Obowiązkowe badania przedślubne, których negatywny wynik uniemożliwiałby zawarcie związku małżeńskiego aż do czasu wyleczenia,

2. Obowiązkowe badania przedślubne, których wyniki byłyby znane nupturientom, bez dalszych negatywnych następstw w zakresie zdolności do zawarcia małżeństwa,

3. Obowiązkowe badania przedślubne, których wyniki byłyby znane tylko osobie badanej,

4. Brak obowiązku badań przedślubnych.

Wspomniany Autor przytacza również wyniki badań socjologicznych prowadzonych przez OBOP $\mathrm{w}$ połowie lat siedemdziesiątych ${ }^{20}$, których przedmiotem był obowiązek lekarskich badań przedślubnych. Z badań tych wynika, że większość ankietowanych opowiedziała się za obowiązkiem tego typu badań (69\% badanych), przy czym dla 26\% respondentów wynik badań nie powinien rodzić dla stron żadnych prawnych konsekwencji, natomiast dla $43 \%$ ankietowanych negatywny wynik badań w zakresie zdrowia psychicznego powinien rodzić skutek w postaci niemożności zawarcia małżeństwa.

Z pewnością warto powrócić do opisanej wyżej propozycji oraz rozważyć możliwość i zasadność ewentualnego wprowadzenia lekarskich

18 Tamże.

19 Szczegółowiej por. M. SAFJAN, W sprawie lekarskich badań przedślubnych, PiP 1974, nr 11, s. 107 i n.

20 Tamże, s. 111. 
badań przedślubnych. Wydaje się, że dobrym punktem wyjścia byłoby przeprowadzenie aktualnych i reprezentatywnych badań aktowych i ankietowych dotyczących wspomnianej problematyki.

W doktrynie dyskutowany jest pogląd, co do dopuszczalności stosowania w odniesieniu do unieważnienia małżeństwa z przyczyn ujętych w art. 12 KRO klauzuli generalnej zasad współżycia społecznego (art. 5 KC). Egzemplifikacją tego poglądu jest wyrok SN z 4 lutego 1985 roku, w którym dopuszcza się możliwość oddalenia powództwa o unieważnienie małżeństwa $\mathrm{z}$ powodu choroby psychicznej na podstawie art. $5 \mathrm{KC}$, jeżeli przemawiają za tym szczególne względy, np. długotrwałe i prawidłowe funkcjonowanie małżeństwa, pochodzenie z małżeństwa dorosłych dzieci ${ }^{21}$. Stanowisko Sądu Najwyższego wyrażone w uzasadnieniu do wskazanego wyżej wyroku spotkało się zarówno z aproba$\mathrm{tą}^{22}$, jak również krytyką ${ }^{23} \mathrm{~W}$ doktrynie. Aprobując rozstrzygnięcie SN w danym stanie faktycznym, zgoła inaczej (krytycznie) należy ocenić stosowania art. $5 \mathrm{KC}$ w sprawach o prawa stanu, zwłaszcza pochodzenia dziecka. Poza argumentami zgłaszanymi w doktrynie, przemawiają za tym również zmiany wprowadzone do Kodeksu rodzinnego i opiekuńczego ostatnią nowelą z dnia 6 listopada 2008 roku w zakresie ustalania pochodzenia dziecka ${ }^{24}$.

Obok opisanych wyżej przeszkód ubezwłasnowolnienia całkowitego oraz choroby psychicznej albo niedorozwoju umysłowego w przepisach Kodeksu rodzinnego i opiekuńczego uregulowano również przeszkodę bigamii. Zgodnie z przepisem art. $13 \mathrm{KRO}$, nie może zawrzeć małżeństwa, „kto już pozostaje w związku małżeńskim”. Omawiana przeszkoda wynika z niekwestionowanej w naszym obszarze kulturowym zasady monogamii ${ }^{25}$. Zasada ta jest przedmiotem ochrony karnoprawnej. Zgod-

21 Por. np. K. Piasecki, op. cit., s. 92; K. Pietrzykowski, op. cit., s. 216 i n.

22 Por. glosa A. SzPunAra, NP. 1986, Nr 6, s. 82 i n.

23 Por. glosa A. Zielonackiego, OSP 1987 Nr 7-8, poz. 132.

24 Por. np. M. KoseK, Nowelizacja prawa rodzinnego na podstawie ustaw z 6 listopada 2008 r. i 10 czerwca 2010r. Analiza, Wyktadania, Komentarz, pod red. W. SToJANOWSKIEJ, Warszawa 2011, s. 113.

25 Szerzej na ten temat por. np. J. MiszTAL-KonecKA, Bigamia w prawie rzymskim, Wydawnictwo KUL, Lublin 2011. 
nie bowiem z przepisem art. 206 Kodeksu karnego bigamia jest przestępstwem, podlegającym karze grzywny, ograniczenia wolności albo jej pozbawienia do lat dwóch ${ }^{26}$. Odpowiedzialności karnej-jak wynika ze wskazanego wyżej przepisu - podlega tylko osoba, która zawarła małżeństwo bigamiczne.

Przeszkoda bigamii znana jest również prawu kanonicznemu, przy czym inne jest źródło pochodzenia omawianego zakazu zawarcia małżeństwa. W prawie kanonicznym przeszkoda ta wynika $\mathrm{z}$ prawa naturalnego.

W celu wykluczenia niebezpieczeństwa zawarcia małżeństwa przez osoby pozostające w związku małżeńskim, art. 3 § 1 KRO (w związku $\mathrm{z}$ art. 54 ust. 1 ustawy Prawo o aktach stanu cywilnego) nakazuje złożenie dowodu ustania lub unieważnienia małżeństwa w odniesieniu do osób zawierających je po raz kolejny.

Podmiotem uprawnionym do ubiegania się o unieważnienie małżeństwa zawartego z naruszeniem przepisu art. $13 \mathrm{KRO}$ jest każdy, kto ma w tym interes prawny $(\S 2)$. Taki zakres podmiotowy wspomnianego uprawnienia jest niewątpliwie wyrazem negatywnego stosunku ustawodawcy do małżeństwa bigamicznego. Interes prawny ma w szczególności każdy z małżonków (małżeństwa bigamicznego) oraz małżonek i dzieci z poprzedniego małżeństwa.

Małżeństwo zawarte z naruszeniem przepisu art. $13 \mathrm{KRO}$ nie może zostać unieważnione, jeżeli poprzednie małżeństwo ustało wskutek śmierci małżonka niebigamisty, wskutek orzeczenia rozwodu lub zostało unieważnione. We wskazanych przypadkach dochodzi do konwalidacji małżeństwa bigamicznego. Ratio legis rozstrzygnięcia ustawodawcy, przewidzianego w $\S 3$ przepisu art. 13 KRO jest w ostateczności zasada ochrony małżeństwa. Małżeństwo bigamiczne może zostać unieważnione tylko wówczas, gdy poprzednie małżeństwo bigamisty trwa. W przypadku, gdy z jakichkolwiek przyczyn przestaje ono istnieć, drugie małżeństwo traci swój wcześniejszy bigamiczny charakter i korzysta

26 Szerzej na ten temat por. np. M. SzEwCZYK, w: Kodeks karny. Część szczegółowa, t. II, Komentarz do art. 117-277 k.k. (pod red. A. ZoLLA), wydanie II, Zakamycze 2006, s. $713 \mathrm{i} \mathrm{n.}$ 
z ochrony. Zasada ta była znana już pod rządami Kodeksu rodzinnego (por. art. 7 §), przy czym powodowała pewne wątpliwości w przypadku śmierci małżonka bigamisty ${ }^{27}$. W obecnym stanie prawnym ustawodawca expressis verbis wyłączył spod tej zasady wskazany przypadek. Unieważnienie małżeństwa bigamicznego jest zatem możliwe w przypadku ustania małżeństwa wcześniejszego, jeżeli jego ustanie nastąpiło w wyniku śmierci małżonka bigamisty.

Katalog przeszkód małżeńskich ukształtowany w Kodeksie rodzinnym i opiekuńczym obejmuje również - z oczywistych powodów - przeszkodę pokrewieństwa (i powinowactwa). Warto najpierw wspomnieć, że w ramach ostatniej nowelizacji tegoż Kodeksu (z 6 listopada 2008 roku) ustawodawca zdefiniował oba pojęcia opisujące omawianą przeszkodę. Zgodnie z przepisem art. $61^{7} \S 1 \mathrm{KRO}$ pojęciem pokrewieństwa obejmuje ustawodawca osoby, z których jedna pochodzi od drugiej. Jest to tak zwane pokrewieństwo w linii prostej. Na określenie osób spokrewnionych w ten właśnie sposób (w linii prostej) ustawodawca posługuje się niekiedy terminami „zstępni” i „,wstępni” (por. np. art. 129 KRO). Pokrewieństwo w linii bocznej odnosi się z kolei do osób, które pochodzą od wspólnego przodka, przy czym nie są krewnymi w linii prostej (np. rodzeństwo). Zgodnie z $§ 2$ przepisu art. $61^{7} \mathrm{KRO}$ stopień pokrewieństwa określa się według liczby urodzeń.

Podstawą pojęcia pokrewieństwa jest więź biologiczna, łącząca określone osoby, na co wskazuje między innymi użycie we wspomnianym przepisie terminu ,pochodzi”. Prawo wiąże z tego typu więzami istotne skutki prawne. W zakresie prawa rodzinnego i opiekuńczego, poza skutkiem w postaci omawianej przeszkody małżeńskiej (art. 14 KRO), wskazać należy np. na unormowania dotyczące obowiązku alimentacyjnego (art. $129 \mathrm{KRO})^{28}$.

$\mathrm{Z}$ kolei powinowactwo - zgodnie z przepisem art. $61^{8} \mathrm{KRO}-$ powstaje w wyniku zawarcia małżeństwa i zachodzi między małżonkiem

27 Por. Z. Wiszniewski, w: Kodeks rodzinny i opiekuńczy. Komentarz, pod red. B. Dobrzańskiego, J. Ignatowicza, wyd. II, Warszawa 1075, s. 50.

28 Por. także przepisy regulujące wybór opiekuna (art. 149 § 2 KRO) oraz przepisy z zakresu prawa spadkowego dotyczące dziedziczenia ustawowego (np. art. $932 \mathrm{KC}$ ). 
a krewnymi drugiego małżonka ${ }^{29}$. Z brzmienia wspomnianego wyżej przepisu wynika, że zawarcie małżeństwa jest konieczną przesłanką powstania powinowactwa. Nie zachodzi ono zatem, gdy małżeństwo zostało zawarte $\mathrm{z}$ naruszeniem art. $1 \S 1 \mathrm{KRO}$ (matrimonium non existens), jak również w przypadku niezaistnienia innych koniecznych przesłanek jego powstania, związanych z określoną formą jego zawarcia (np. art. $1 \S$ $2 \mathrm{KRO}$ ). Nie jest natomiast ,przeszkodą" w powstaniu powinowactwa zawarcie małżeństwa $\mathrm{z}$ naruszeniem omawianych przepisów art. 10-15 KRO. Małżeństwo zostaje wówczas zawarte, przy czym może zostać unieważnione.

Zgodnie $\mathrm{z}$ art. $61^{8} \S 1 \mathrm{KRO}$ powinowactwo trwa mimo ustania małżeństwa. Ten stosunek prawny wiąże zatem określone podmioty mimo śmierci jednego z małżonków (uznania małżonka za zmarłego) oraz rozwiązania małżeństwa przez rozwód.

$\mathrm{Z}$ powinowactwem prawo wiąże określone skutki. W zakresie prawa rodzinnego - poza przeszkodą małżeńską uregulowaną w art. $14 \mathrm{KRO}$ - wymienić należy art. 144 KRO (obowiązek alimentacyjny miedzy ojczymem/macochą a pasierbem) oraz art. $90 \mathrm{KRO}$ (możliwość nadania pasierbowi nazwiska ojczyma).

Zakres omawianej przeszkody obejmuje krewnych w linii prostej oraz rodzeństwo, jak również powinowatych w linii prostej. W odniesieniu do krewnych objętych treścią art. 14 KRO przeszkoda ma charakter bezwzględny. Konsekwencją takiego rozstrzygnięcia jest niemożność konwalidacji małżeństwa zawartego między krewnymi w linii prostej lub rodzeństwem. W stosunku do powinowatych ustawodawca przewiduje możliwość zawarcia małżeństwa po uprzedniej zgodnie sądu.

Racją omawianej przeszkody są względy natury obyczajowej i eugenicznej.

29 Stosunek powinowactwa nie zachodzi natomiast między: jednym z małżonków a osobą, która pozostaje w związku małżeńskim z krewnym drugiego małżonka, jednym $\mathrm{z}$ małżonków a powinowatymi drugiego małżonka, powinowatymi jednego z małżonków z powinowatymi drugiego małżonka, krewnymi jednego z małżonków z krewnymi drugiego z małżonków. Szerzej por. M. KosEK, w: Nowelizacja prawa rodzinnego na podstawie ustaw z 6 listopada 2008 r. i 10 czerwca 2010r. op. cit., s. 97. 
W przepisie art. 15 KRO ustawodawca prawno-rodzinny unormował przeszkodę przysposobienia. Przeszkoda ta wynika z istoty stosunku przysposobienia, którego celem jest ukształtowanie między podmiotami tego stosunku takiej relacji, jaka zachodzi między rodzicem a dzieckiem. Przeszkoda ta wykazuje w tym aspekcie pewne podobieństwo do przedstawionej wyżej przeszkody pokrewieństwa (nazywana jest niekiedy przeszkodą ,pokrewieństwa” prawnego), co dla części autorów stanowi wystarczającą podstawę formułowania postulatu co do jej uchylenia $^{30}$.

Warto $\mathrm{w}$ tym kontekście przypomnieć, że prawo polskie przewiduje trzy rodzaje przysposobienia - niepełne, pełne (rozwiązywalne) i pełne nierozwiązywalne (nazywane w doktrynie całkowitym) ${ }^{31}$. Każdy z wskazanych wyżej rodzajów przysposobienia stanowi przeszkodę w zawarciu małżeństwa. Rozwiązanie stosunku przysposobienia powoduje ustanie przeszkody.

\section{Uwagi końcowe}

Problematyka przeszkód małżeńskich przynależy do kompleksu zagadnień wchodzących w skład unormowań Kodeksu rodzinnego i opiekuńczego w zakresie zawarcia małżeństwa. Zarówno z teoretycznego, jak i praktycznego punktu widzenia jest to problematyka ważna i aktualna, choć niezbyt często podejmowana w literaturze przedmiotu.

Scharakteryzowany w niniejszym artykule katalog przeszkód małżeńskich, przewidzianych przez polskiego ustawodawcę (art. 10-15 KRO), jest w doktrynie w zasadzie akceptowany, co oczywiście nie wyłącza dyskusji w odniesieniu do niektórych przepisów dotyczących omawianej problematyki. Jako przykład można wskazać przepis art. $12 \mathrm{KRO}$, który - być może - będzie wymagał interwenji ustawodawcy.

30 Por. np. A. ZielonACKi, op. cit., s. 69.

31 Szerzej na ten temat por. E. HolewińskA-ŁaPIŃSKA, w: System Prawa Prywatnego, t, 12, Prawo rodzinne i opiekuńcze, pod red. T. SMYCZYŃSKIEGO, wyd. 2, Warszawa 2011, s. $648 \mathrm{i} \mathrm{n.}$ 


\section{Marriage impediment in the Polish Family and Guardianship Code}

The article is an extended version of the study presented during a scientific conference organized by the Faculty of Canon Law of Cardinal Stefan Wyszynski University in Warsaw on $25^{\text {th }}$ April 2012 dedicated to marriage impediments under Polish law and Canon law.

The article contains a study of the provisions of the Family and Guardianship Code regulating impediments to marriage. The first part presents the very beginning of the provisions in that matter under Polish law and a list of different types of impediments to marriage. The second part embraces a specific description of the types of impediments to marriage with special regard to the full legal incapacitation and mental illness or retardation impediment. The article does not cover the age impediment (Art. 10 of the Family and Guardianship Code) since it was the subject of a separate study at the abovementioned conference. 